\title{
Soybean Resistance to Cercospora sojina Infection Is Reduced by Silicon
}

\author{
Kelly Juliane Telles Nascimento, Daniel Debona, Sueny Kelly Santos França, \\ Mariana Gabriele Marcolino Gonçalves, Fábio Murilo DaMatta, and Fabrício Ávila Rodrigues
}

First and fifth authors: Universidade Federal de Viçosa (UFV), Departamento de Biologia Vegetal, Viçosa, Minas Gerais State, 36570-900, Brazil; and second, third, fourth, and sixth authors: UFV, Departamento de Fitopatologia, Laboratório da Interação Planta-Patógeno, Viçosa, Minas Gerais State, 36570-900, Brazil.

Accepted for publication 28 April 2014.

\begin{abstract}
Nascimento, K. J. T., Debona, D., França, S. K. S., Gonçalves, M. G. M., DaMatta, F. M., and Rodrigues, F. A. 2014. Soybean resistance to Cercospora sojina infection is not enhanced by silicon. Phytopathology 104:1183-1191.

Frogeye leaf spot, caused by Cercospora sojina, is one of the most important leaf diseases of soybean worldwide. Silicon $(\mathrm{Si})$ is known to increase the resistance of several plant species to pathogens. The cultivars Bossier and Conquista, which are susceptible and resistant, respectively, to frogeye leaf spot, supplied and nonsupplied with Si were examined for the activities of defense enzymes and the concentrations of total soluble phenolics (TSP) and lignin-thioglycolic acid (LTGA) derivatives at 8, 14,

plants were grown in hydroponic culture containing either 0 or $2 \mathrm{mM} \mathrm{Si}$ ( $-\mathrm{Si}$ and $+\mathrm{Si}$, respectively) and noninoculated or $C$. sojina inoculated. Severity of frogeye leaf spot was higher in cultivar Bossier plants than cultivar Conquista and also in the +Si plants compared with their $-\mathrm{Si}$ counterparts. Except for the concentrations of TSP and LTGA derivatives, activities of defense enzymes and the CWDE did not change for $+\mathrm{Si}$ noninoculated plants regardless of the cultivar. The activities of lipoxygenases, phenylalanine ammonia-lyases, chitinases, and polyphenoloxidases as well as the activities of CWDE decreased for the $+\mathrm{Si}$ inoculated plants. The results from this study demonstrated that defense enzyme activities decreased in soybean plants supplied with $\mathrm{Si}$, which compromised resistance to $C$. sojina infection.
\end{abstract} and 16 days after inoculation (dai) with $C$. sojina. The importance of cell wall degrading enzymes (CWDE) to the infection process of $C$. sojina and the effect of $\mathrm{Si}$ on their activities were also determined. Soybean
Additional keywords: foliar disease, Glycine max.
Frogeye leaf spot, caused by the necrotrophic fungus Cercospora sojina $\mathrm{K}$. Hara, is one of the most destructive foliar soybean diseases and affects yields worldwide $(29,43)$. On leaves, symptoms begin as dark, water-soaked circular to somewhat irregular spots with light centers (2). As the lesions expand, the centers turn light brown to light gray in color, and they develop light centers with a darker red to purple-brown border as they age $(2,29)$. On stems and pods, the lesions initially look similar to those observed on leaves, but develop into very dark brown, circular spots (2). On the seed tegument, $C$. sojina infection causes cracks and brown to gray lesions of different shapes and sizes $(2,29)$.

The intensity of frogeye leaf spot increases in soybean growing in regions with warm and humid environmental conditions (29). Control of frogeye leaf spot has mainly been achieved through resistant cultivars and fungicide sprays (29). Race-specific resistance to $C$. sojina in soybean is conferred by the $R \operatorname{cs} 3$ gene (47), which imposes intense selective pressure on the pathogen population, and the risk of severe disease epidemics has become eminent (2,33).

Due to the yield losses caused by frogeye leaf spot, new disease management strategies need to be investigated. One of the greatest benefits of silicon ( $\mathrm{Si}$ ) to many plant species is the reduction of the intensities of several diseases caused by soilborne and foliar pathogens (16). Hayasaka et al. (30) reported a decrease in

Corresponding author: F. A. Rodrigues; E-mail address: fabricio@ufv.br

http://dx.doi.org/10.1094/PHYTO-02-14-0047-R

(C) 2014 The American Phytopathological Society the number of blast lesions on the leaves of rice plants supplied with Si; Pyricularia oryzae penetration was prevented or slowed by the formation of a thick silica layer below the cuticle. Moreover, several examples in the literature show that $\mathrm{Si}$ is involved in enhancing host defenses, such as increasing the concentrations of soluble phenolics, lignin, and phytoalexins. In addition, Si increases the activity of several defense enzymes and the transcription level of genes that code for $\beta$-1,3-glucanases, peroxidases, and pathogenesis-related protein 1 (PR-1) $(21,42,54,55)$. Rodrigues et al. (52) reported that, in rice plants supplied with $\mathrm{Si}$, the hydrolysis of leaf cellulose caused by cellulases released by $P$. oryzae was dramatically reduced. Many of the $P$. oryzae hyphae were surrounded or trapped in an amorphous material that stained densely with toluidine blue and reacted positively to osmium tetroxide, which indicated the presence of phenolic-like compounds. Fortunato et al. (21) reported that the severity of Fusarium wilt on banana plants supplied with $\mathrm{Si}$ decreased as a consequence of an increase in the activities of phenylalanine ammonia-lyases, polyphenoloxidases, chitinases, $\beta$-1,3-glucanases, and peroxidases as well as higher concentrations of total soluble phenolics (TSP) and lignin. In soybean in particular, rust (Phakopsora pachyrhizi) severity and the number of pustules were significantly reduced on leaves sprayed with potassium silicate (53). Lemes et al. (39) also demonstrated that the onset of symptoms of soybean rust was delayed by approximately 3 days, and the area under the disease progress curve was reduced for plants either grown in soil amended with calcium silicate or sprayed with potassium silicate. Arsenault-Labrecque et al. (3) also found that soybean resistance to $P$. pachyrhizi infection greatly improved in plants supplied with $\mathrm{Si}$. Cruz et al. (14) reported 
reductions of 27,23 , and $60 \%$ in the number of lesions, closed uredia, and open uredia, respectively, in the leaflets of soybean plants supplied with Si. In another study, Cruz et al. (13) found that soybean plants grown in soil amended with calcium silicate showed increased activity of chitinases, $\beta$-1,3-glucanases, and phenylalanine ammonia-lyases, all of which contributed to decreased rust severity.

To the best of our knowledge, information in the literature regarding the effect of $\mathrm{Si}$ on frogeye leaf spot development is lacking. Therefore, the objective of the present study was to determine the effect of $\mathrm{Si}$ on soybean defense mechanisms at the biochemical level (the activities of the enzymes phenylalanine ammonia-lyases, polyphenoloxidases, chitinases, $\beta$-1,3-glucanases, peroxidases, and lipoxygenases as well as the concentrations of phenolics and lignin) in two cultivars with different basal levels of resistance to frogeye leaf spot. Additionally, the study investigated whether cell wall degrading enzymes (cellulases, xylanases, pectin methyl esterases, and polygalacturonases) could have their activities reduced on plants supplied with $\mathrm{Si}$ during $C$. sojina infection.

\section{MATERIALS AND METHODS}

Nutrient solution preparation. The nutrient solution used in this study was prepared according to Clark (12), with some modifications, and included the following nutrients: $1.04 \mathrm{mM}$ $\mathrm{Ca}\left(\mathrm{NO}_{3}\right)_{2} \cdot 4 \mathrm{H}_{2} \mathrm{O}, 1 \mathrm{mM} \mathrm{NH} \mathrm{NO}_{3}, 0.8 \mathrm{mM} \mathrm{KNO}, 0.069 \mathrm{mM}$ $\mathrm{KH}_{2} \mathrm{PO}_{4}, 0.931 \mathrm{mM} \mathrm{KCl}, 0.6 \mathrm{mM} \mathrm{MgSO}{ }_{4} \cdot 7 \mathrm{H}_{2} \mathrm{O}, 19 \mu \mathrm{M} \mathrm{H}_{3} \mathrm{BO}_{3}$, $2 \mu \mathrm{M} \mathrm{ZnSO}{ }_{4} \cdot 7 \mathrm{H}_{2} \mathrm{O}, 0.5 \mu \mathrm{M} \mathrm{CuSO} \mathrm{Cu}_{4} \cdot 5 \mathrm{H}_{2} \mathrm{O}, 7 \mu \mathrm{M} \mathrm{MnCl}_{2} \cdot 4 \mathrm{H}_{2} \mathrm{O}$, $0.6 \mu \mathrm{M} \mathrm{Na}_{2} \mathrm{MoO}_{4} \cdot 4 \mathrm{H}_{2} \mathrm{O}, 60 \mu \mathrm{M} \mathrm{FeSO} \cdot 7 \mathrm{H}_{2} \mathrm{O}$, and $90 \mu \mathrm{M}$ EDTA disodium. The $\mathrm{Si}$ was supplied as monosilicic acid, which was obtained by passing potassium silicate (PQ Corporation, São Paulo, Brazil) through a cation exchange resin (Amberlite IR120B, $\mathrm{H}^{+}$form; Sigma-Aldrich, São Paulo, Brazil) (44). Silicon was added to the nutrient solution in concentrations of $0 \mathrm{mM}$ $(-\mathrm{Si})$ or $2 \mathrm{mM}(+\mathrm{Si})$.

Plant growth. Seeds of cultivars Bossier and Conquista, which are susceptible or resistant to frogeye leaf spot, respectively (23), were surface sterilized in $10 \%$ (vol/ $/ \mathrm{vol}$ ) $\mathrm{NaOCl}$ for $3 \mathrm{~min}$ and then rinsed in sterilized water and germinated on distilled watersoaked germitest paper in a germination chamber (MA-835/ 2106UR; Marconi, São Paulo, Brazil) at $25^{\circ} \mathrm{C}$ for 6 days. Germinated seedlings were transferred to 25 -cm-diameter plastic pots with one-fourth strength nutrient solution without Si. After 2 days, three seedlings were transferred to each new plastic pot, which contained 5 liters of nutrient solution either with or without $\mathrm{Si}$ under aeration, where they stayed until the end of the experiments. The nutrient solution was changed every 4 days or when its electrical conductivity reached $85 \%$ of the initial value. The $\mathrm{pH}$ was checked daily and kept at $\approx 5.5$ using $\mathrm{NaOH}$ or $\mathrm{HCl} 1 \mathrm{M}$. Plants were grown in a greenhouse, temperature of $30 \pm 5^{\circ} \mathrm{C}$, relative humidity of $65 \pm 5 \%$, and natural photosynthetically active radiation of $900 \pm 15 \mu \mathrm{mol}$ photons $\mathrm{m}^{-2} \mathrm{~s}^{-1}$, which was measured at midday until inoculation with $C$. sojina.

Inoculation procedure. A pathogenic isolate of $C$. sojina (UFV-DFP-22), which was preserved on strips of filter paper placed into glass tubes containing silica gel at $4^{\circ} \mathrm{C}$, was used to inoculate the plants. Ten days before inoculation, pieces of filter paper containing fungal mycelia were placed in Petri dishes containing potato dextrose agar (PDA). Discs of the PDA with fungal mycelia were transferred to new Petri dishes containing V8 juice agar medium. These Petri dishes were maintained in a growth chamber with a 12-h photoperiod at $25^{\circ} \mathrm{C}$ for 7 days. Conidia were then carefully removed from the Petri dishes with a softbristle brush using water amended with gelatin $(1 \% \mathrm{wt} / \mathrm{vol})$. Plants were allowed to grow for 20 days (V6 growth stage) (20) in a hydroponic culture containing 0 or $2 \mathrm{mM} \mathrm{Si}$ and then inoculated with a conidial suspension of $C$. sojina $\left(4 \times 10^{4}\right.$ conidia/ml $)$ that was applied as a fine mist with a VL Airbrush atomizer (Paache Airbrush Co., Chicago, IL) to both the adaxial and abaxial leaves of each plant until runoff. After inoculation, plants were maintained in a plastic mist growth chamber (MGC) inside a greenhouse for the duration of the experiments. The MGC was constructed of wood ( $2 \mathrm{~m}$ wide, $1.5 \mathrm{~m}$ high, and $5 \mathrm{~m}$ long) and covered with transparent plastic $(100 \mu \mathrm{m}$ thick). The maximum natural photon flux density at plant canopy height was $\approx 700 \mu \mathrm{mol}$ $\mathrm{m}^{-2} \mathrm{~s}^{-1}$, and the temperature was $25 \pm 2^{\circ} \mathrm{C}$ (day) and $20 \pm 2^{\circ} \mathrm{C}$ (night). The relative humidity was maintained at $92 \pm 3 \%$ with a misting system in which nozzles (model NEB-100, KGF Co., São Paulo, Brazil) sprayed mist every $30 \mathrm{~min}$ for $15 \mathrm{~s}$ above the plant canopy. The temperature and relative humidity were measured with a thermohygrograph (TH-508, Impac, Brazil).

Assessment of frogeye leaf spot severity. Frogeye leaf spot severity was assessed for the sixth trifoliolate leaf of each plant at 16 days after inoculation (dai). After assessment, diseased leaves were removed from all plants and scanned at 600 dpi resolution. The images were processed to determine the severity of frogeye leaf spot using the software QUANT (Viçosa Federal University, Department of Plant Pathology, Brazil) (62).

Determination of foliar Si concentration. After determining the frogeye leaf spot severity, leaves from the plants from each replication and treatment were collected, washed with deionized water, and dried at $65^{\circ} \mathrm{C}$ for $72 \mathrm{~h}$. Next, the leaves were ground in a Thomas-Wiley mill with a 40-mesh sieve, and the concentration of $\mathrm{Si}$ was determined by colorimetric analysis of $0.1 \mathrm{~g}$ of alkaline digested dry leaf tissue (36).

Biochemical assays. For all biochemical assays, the fourth, fifth, and sixth trifoliolate leaves from the plants of each replication and treatment were collected at 8,14 , and 16 dai. Leaves were also collected from noninoculated plants at these same sampling times. To determine the activity of lipoxygenases (LOX, EC 1.13.11.12), phenylalanine ammonia-lyases (PAL, EC 4.3.1.5), $\beta$-1,3-glucanases (GLU, EC 3.2.1.6), chitinases (CHI, EC 3.2.1.14), peroxidases (POX, EC 1.11.1.7), polyphenoloxidases (PPO, EC 1.10.3.1), cellulases (CEL, 3.2.1.4), xylanases (XYL, EC 3.2.1.8), pectin methyl esterases (PME, EC 3.1.1.11), and polygalacturonases (PG, EC 3.2.1.15), a total of $0.3 \mathrm{~g}$ of leaf tissue was ground into a fine powder with liquid nitrogen in a mortar and pestle. The fine powder was homogenized in $2 \mathrm{ml}$ of a

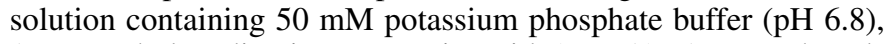
$1 \mathrm{mM}$ ethylenediaminetetraacetic acid (EDTA), $1 \mathrm{mM}$ phenylmethylsulfonyl fluoride (PMSF), and 2\% (wt/vol) polyvinylpyrrolidone (PVP) in an ice bath. The homogenate was centrifuged at $12,000 \times g$ for $15 \mathrm{~min}$ at $4^{\circ} \mathrm{C}$. The supernatant was used to determine the activities of LOX, PAL, GLU, CHI, and PPO. For POX that was ionically bound to the cell wall, a total of $0.3 \mathrm{~g}$ of leaf tissue was ground into a fine powder with liquid nitrogen in a mortar and pestle. The powder was homogenized in an ice bath in $2 \mathrm{ml}$ of the solution described above. The homogenate was centrifuged at $1,000 \times g$ for $10 \mathrm{~min}$ at $4^{\circ} \mathrm{C}$ and once more for the same amount of time and at the same temperature (49). The resulting pellet was washed twice with the solution described above, then with water at $4{ }^{\circ} \mathrm{C}$ and then incubated in $2 \%(\mathrm{vol} / \mathrm{vol})$ Triton X-100 at $4^{\circ} \mathrm{C}$ under continuous shaking for $1 \mathrm{~h}$. The pellet was again washed twice using $4^{\circ} \mathrm{C}$ water and incubated in a solution containing $1 \mathrm{M} \mathrm{NaCl}$ for $2 \mathrm{~h}$ at $4^{\circ} \mathrm{C}$. This solution was centrifuged at $1,000 \times g$ for $10 \mathrm{~min}$ at $4^{\circ} \mathrm{C}$. The pellet was discarded, and the supernatant was used to determine the activity of the POX ionically bound to the cell wall.

Activity of LOX was determined by adding $10 \mu \mathrm{l}$ of the crude enzyme extract to a reaction mixture containing $50 \mathrm{mM}$ sodium phosphate buffer ( $\mathrm{pH}$ 6.5) and $50 \mu \mathrm{M}$ sodium linoleate. The reaction mixture was incubated at $25^{\circ} \mathrm{C}$, and the absorbance of the product released by LOX for 1 min was measured at $234 \mathrm{~nm}$. The extinction coefficient of $25,000 \mathrm{M}^{-1} \mathrm{~cm}^{-1}$ was used to calculate LOX activity (4). 
Activity of PAL was determined by following the methodology proposed by Guo et al. (24) with some modifications. The reaction was started following the addition of $100 \mu$ of the crude enzyme extract to a reaction mixture containing $40 \mathrm{mM}$ sodium borate buffer $(\mathrm{pH} 8.8)$ and $20 \mathrm{mM} \mathrm{L}$-phenylalanine in a total volume of $1 \mathrm{ml}$. The reaction mixture was incubated in a water bath at $30^{\circ} \mathrm{C}$ for $1 \mathrm{~h}$, and the reaction was stopped by the addition of $50 \mu \mathrm{l}$ of $\mathrm{HCl} 6 \mathrm{~N}$. The absorbance of trans-cinnamic acid derivatives was measured at $290 \mathrm{~nm}$. A similar procedure was used for the control samples, but the reaction was immediately stopped after the addition of the crude enzyme extract to the reaction mixture. The extinction coefficient of $100 \mathrm{M}^{-1} \mathrm{~cm}^{-1}$ was used to calculate PAL activity (65).

Activity of GLU was determined by adding $20 \mu \mathrm{l}$ of the crude enzyme extract to a reaction mixture containing $50 \mathrm{mM}$ sodium acetate buffer $(\mathrm{pH} \mathrm{5.0)}$ and laminarin $(1 \mathrm{mg} / \mathrm{ml})(40)$. The reaction mixture was incubated in a water bath at $45^{\circ} \mathrm{C}$ for $1 \mathrm{~h}$. Next, $500 \mu \mathrm{l}$ of this mixture was added to a reaction mixture of dinitrosalicylic acid (DNS). This reaction mixture was then incubated in a water bath for $15 \mathrm{~min}$ at $100^{\circ} \mathrm{C}$ and then cooled in an ice bath until it reached $25^{\circ} \mathrm{C}$. The absorbance was measured at $540 \mathrm{~nm}$, and the amount of reducing sugars released was calculated with a calibration curve using glucose (Sigma-Aldrich, São Paulo, Brazil) as a standard (46). A similar procedure was used for the control samples except that the first incubation was excluded.

Activity of CHI was determined according to the method of Harman et al. (28). The reaction was started with the addition of $20 \mu \mathrm{l}$ of the crude enzyme extract to a reaction mixture containing $50 \mathrm{mM}$ sodium acetate buffer $(\mathrm{pH} 5.0)$ and $0.1 \mathrm{mM} p$-nitrophenyl- $\beta-D-N-N{ }^{\prime}$-diacetylchitobiose. The reaction mixture was incubated in a water bath at $37^{\circ} \mathrm{C}$ for $2 \mathrm{~h}$, and the reaction was terminated by adding $500 \mu \mathrm{l}$ of $0.2 \mathrm{M}$ sodium carbonate. For the control samples, the sodium carbonate was added soon after the addition of the crude enzyme extract to the reaction mixture. The absorbance of the end product released by $\mathrm{CHI}$ was measured at $410 \mathrm{~nm}$, and the extinction coefficient of $70 \mathrm{mM}^{-1} \mathrm{~cm}^{-1}$ was used to calculate $\mathrm{CHI}$ activity.

Activity of POX ionically bound to the cell wall was determined by adding $100 \mu \mathrm{l}$ of the crude enzyme extract to the reaction mixture containing $25 \mathrm{mM}$ potassium phosphate buffer ( $\mathrm{pH}$ 6.8), $20 \mathrm{mM}$ pyrogallol, and hydrogen peroxide in $2 \mathrm{ml}$ (32). The reaction was started after the addition of $15 \mu$ of the crude enzyme extract, and the absorbance was determined at $420 \mathrm{~nm}$ for $1 \mathrm{~min}$ at $25^{\circ} \mathrm{C}$. The extinction coefficient of $2.47 \mathrm{mM}^{-1} \mathrm{~cm}^{-1}$ was used to calculate the activity of POX ionically bound to the cell wall (11). The PPO activity was determined using the same procedure as for POX, but the hydrogen peroxide was omitted from the reaction mixture.

Activity of CEL was determined following the method described by Ahmed and Labavitch (1). The reaction was started after the addition of $75 \mu \mathrm{l}$ of the crude enzyme extract to a reaction mixture containing $100 \mathrm{mM}$ sodium acetate buffer $(\mathrm{pH}$ $5.0)$ and $1.5 \%(\mathrm{wt} / \mathrm{vol})$ carboxymethylcellulose in $1 \mathrm{ml}$. The reaction mixture was incubated in a water bath at $37^{\circ} \mathrm{C}$ for $16 \mathrm{~h}$ and then $250 \mu \mathrm{l}$ of DNS was added. The reaction mixture was incubated again in a water bath at $100^{\circ} \mathrm{C}$ for $7 \mathrm{~min}$ and then cooled in an ice bath until it reached $25^{\circ} \mathrm{C}$. The absorbance of the product released by $\mathrm{CEL}$ was measured at $540 \mathrm{~nm}$. The amount of reducing sugars released was calculated from a calibration curve using glucose (Sigma-Aldrich, São Paulo, Brazil) as a standard (46). For the control samples, a similar procedure was followed except that the first incubation was excluded.

Activity of XYL was determined after the addition of $150 \mu \mathrm{l}$ of the crude enzyme extract to a reaction mixture containing $100 \mathrm{mM}$ sodium acetate buffer ( $\mathrm{pH} 5.0)$ and $0.1 \%$ (wt/vol) xylan in $1 \mathrm{ml}(59)$. The reaction mixture was incubated in a water bath at $37^{\circ} \mathrm{C}$ for $1 \mathrm{~h}$, and the concentration of reducing sugars was quantified as described for the CEL.
Activity of PME was determined as described by Hagerman and Austin (25) with a few modifications. The reaction was started following the addition of $100 \mu \mathrm{l}$ of the crude enzyme extract to a reaction mixture constituted of $0.01 \%$ pectin $(\mathrm{pH} 7.5)$, $0.15 \mathrm{M} \mathrm{NaCl}$, and $100 \mu \mathrm{l}$ of $0.01 \%$ bromothymol blue in $2 \mathrm{ml}$. The absorbance was measured at $620 \mathrm{~nm}$ soon after the addition of the crude enzyme extract to the reaction mixture and again after 3 min. PME activity was determined from the difference between the initial and final absorbance readings using a calibration curve with pectin (Sigma-Aldrich, São Paulo, Brazil) as a standard.

Activity of PG was determined by adding $75 \mu \mathrm{l}$ of the crude enzyme extract to a reaction mixture containing $40 \mathrm{mM}$ sodium acetate buffer ( $\mathrm{pH} 4.5)$ and $0.3 \%$ (wt/vol) polygalacturonic acid $(\mathrm{pH} 4.5)$ in $1 \mathrm{ml}$. The reaction mixture was incubated in a water bath at $37^{\circ} \mathrm{C}$ for $1 \mathrm{~h}$ and then $250 \mu \mathrm{l}$ of DNS was added. The reaction was incubated again in a water bath at $100^{\circ} \mathrm{C}$ for $10 \mathrm{~min}$ and then it was cooled in an ice bath until it reached $25^{\circ} \mathrm{C}$. The absorbance of the product released by $\mathrm{PG}$ was measured at $540 \mathrm{~nm}$. For the control samples, a similar procedure was used except that the first incubation was excluded. Under the conditions previously described, one unit of PG catalyzed the release of $1 \mathrm{nmol}$ of galacturonic acid in one second (48).

Enzyme activity was expressed based on protein whose concentration was determined according to the method of Bradford (7).

Determination of the concentrations of TSP and ligninthioglycolic acid (LTGA) derivatives. A total of $0.1 \mathrm{~g}$ of leaf tissue was ground into a fine powder with liquid nitrogen in a mortar and pestle and homogenized in $1 \mathrm{ml}$ of a solution containing $80 \%$ ( $\mathrm{vol} / \mathrm{vol})$ methanol in an ice bath. The homogenate was placed in a shaker at $300 \mathrm{rpm}$ for $2 \mathrm{~h}$ at $25^{\circ} \mathrm{C}$ and then centrifuged at $17,000 \times g$ for $30 \mathrm{~min}$. The supernatant was used to determine TSP concentration, and the pellet was maintained at $20^{\circ} \mathrm{C}$ to determine the concentration of LTGA derivatives. The concentration of TSP was determined by following the methodology proposed by Zieslin and Ben-Zaken (64) with modifications proposed by Rodrigues et al. (54). The reaction was started after the addition of $0.2 \mathrm{M}$ Folin-Ciocalteu phenol reagent to $150 \mu \mathrm{l}$ of the methanolic extract and kept at $25^{\circ} \mathrm{C}$ for $5 \mathrm{~min}$. Next, $0.1 \mathrm{M}$ sodium carbonate was added to the solution, which was maintained at $25^{\circ} \mathrm{C}$ for $10 \mathrm{~min}$. Afterward, $1 \mathrm{ml}$ of deionized water was added to the mixture and it was incubated at $25^{\circ} \mathrm{C}$ for $1 \mathrm{~h}$. The absorbance was read at $725 \mathrm{~nm}$, and the TSP concentration was calculated based on a calibration curve using catechol (SigmaAldrich, São Paulo, Brazil) as a standard. For the concentration of LTGA derivatives, the pellet was resuspended in $1.5 \mathrm{ml}$ of deionized water, and the homogenate was centrifuged at $12,000 \times g$ for $15 \mathrm{~min}$. The supernatant was discarded and the pellet was dried at $65^{\circ} \mathrm{C}$ for $12 \mathrm{~h}$. The alcohol-insoluble dry residue was used to determine the concentration of LTGA derivatives as described by Barber and Ride (5). The absorbance of the LTGA derivatives supernatant was read at $280 \mathrm{~nm}$, and its concentration was determined by a calibration curve using lignin, alkali, and 2-hydroxypropyl ether (Sigma-Aldrich, São Paulo, Brazil) as a standard.

Experimental design and data analysis. A $2 \times 2$ factorial experiment with four replications, consisting of two Si concentrations $(0$ or $2 \mathrm{mM}$, referred to as $-\mathrm{Si}$ and $+\mathrm{Si}$ plants, respectively) and two cultivars (Bossier and Conquista) arranged in a completely randomized design, was used to evaluate frogeye leaf spot severity and foliar Si concentration. A $2 \times 2 \times 2$ factorial experiment with four replications, consisting of two $\mathrm{Si}$ concentrations, two cultivars, and plant inoculation (noninoculated and inoculated plants) with a completely randomized design, was used to evaluate the biochemical variables. The analysis of variance (ANOVA) for this experiment tested $2 \times 2 \times 2 \times 3$ factors consisting of two Si concentrations, two cultivars, both noninoculated 
and inoculated plants, and three sampling times (8, 14, and 16 dai). Each experimental unit consisted of a plastic pot with three plants, and all experiments were repeated once. Data from all variables were analyzed by ANOVA, and means from noninoculated and inoculated plants or $-\mathrm{Si}$ and $+\mathrm{Si}$ treatments for each cultivar and evaluation time were compared using $t$ tests $(P \leq$ 0.05) using SAS (version 6.12; SAS Institute, Inc., Cary, NC).

\section{RESULTS}

Foliar Si concentration. Only the Si concentration factor was significant for foliar Si concentration (Table 1). Foliar Si concentration was significantly greater in the $+\mathrm{Si}$ plants $(7.6 \mathrm{~g} / \mathrm{kg})$ compared with the - Si plants $(2.5 \mathrm{~g} / \mathrm{kg})$.

Frogeye leaf spot severity. The $\mathrm{Si}$ concentrations, cultivars, and the interaction $\mathrm{Si}$ concentrations $\times$ cultivars were significant for the severity of frogeye leaf spot (Table 1). Frogeye leaf spot severity increased by 583 and $230 \%$ in + Si plants for Bossier and Conquista, respectively, compared with the $-\mathrm{Si}$ cultivars. The severity of frogeye leaf spot was significantly reduced by 91 and $96 \%$, respectively, for the $-\mathrm{Si}$ and $+\mathrm{Si}$ plants of Conquista in comparison with the $-\mathrm{Si}$ and $+\mathrm{Si}$ plants of Bossier.

Biochemical variables. The activities of LOX, PAL, GLU, CHI, POX, PPO, CEL, XYL, PME, and PG as well as the concentrations of TSP and LTGA derivatives were significantly influenced by at least one of the factors studied and some of the two-way, three-way, and four-way interactions (Table 1). For noninoculated plants, regardless of the cultivar, there were no significant differences between the $-\mathrm{Si}$ and $+\mathrm{Si}$ plants in the activities of LOX, PAL, GLU, CHI, POX, PPO, CEL, XYL, and PME or in the concentrations of TSP and LATG derivatives (Figs. 1 and 2). In Bossier inoculated plants, the activities of LOX and POX were higher in the $-\mathrm{Si}$ plants compared with the $+\mathrm{Si}$ plants at 8,14 , and 16 dai (Fig. 1). CHI activity in -Si plants was lower at 14 dai and higher at 16 dai in comparison with the + Si plants (Fig. 1). The activities of PPO and PAL were greater at 8 and 16 dai, respectively, in the $-\mathrm{Si}$ plants than in the $+\mathrm{Si}$ plants (Fig. 1). GLU activity was not affected by $\mathrm{Si}$ (Fig. 1). For the $-\mathrm{Si}$ inoculated plants of Conquista, PAL and POX activities were higher at 8,14 , and 16 dai compared with the + Si plants (Fig. 1). LOX activity was higher in the $-\mathrm{Si}$ plants at 8 and 14 dai and lower at 16 dai when compared with the $+\mathrm{Si}$ plants (Fig. 1). GLU activity was higher for the $-\mathrm{Si}$ plants than for the $+\mathrm{Si}$ plants at 14 and 16 dai (Fig. 1), and $\mathrm{CHI}$ and PPO activities were higher at 8 dai in the $-\mathrm{Si}$ plants than the $+\mathrm{Si}$ plants (Fig. 1). For the $-\mathrm{Si}$ inoculated plants of Bossier, LOX activity was higher at 8 dai and lower at 14 and 16 dai when compared with noninoculated plants (Fig. 1). PPO activity was higher and lower at 8 and 14 dai, respectively, for the inoculated plants than the noninoculated plants (Fig. 1). The activities of PAL, GLU, CHI, and POX were higher in the inoculated plants compared to the noninoculated plants at 8, 14, and 16 dai (Fig. 1). For the $+\mathrm{Si}$ inoculated plants of Bossier, there were higher PAL, GLU, CHI, and POX activities and lower LOX activity compared with the noninoculated plants at 8,14 , and 16 dai (Fig. 1). PPO activity was higher at 8 dai and lower at 14 and 16 dai for the inoculated plants than the noninoculated plants (Fig. 1). For the -Si inoculated plants of cultivar Conquista, there were higher PAL, CHI, and POX activities compared with their noninoculated counterparts at 8,14 , and 16 dai (Fig. 1). The activity of LOX was higher at 8 and 14 dai and lower at 16 dai in the inoculated plants than in the noninoculated plants (Fig. 1). The activity of PPO was higher in the inoculated plants at 8 and 14 dai compared with the noninoculated plants (Fig. 1). GLU activity was higher for inoculated plants than the noninoculated plants at 8 dai (Fig. 1). In $+\mathrm{Si}$ inoculated plants of cultivar Conquista, $\mathrm{CHI}$ and POX activities were higher than in the noninoculated plants at 8, 14, and 16 dai (Fig. 1). There was higher LOX activity at 8 and 14 dai and higher PAL activity at 14 and 16 dai in the inoculated plants compared with the noninoculated plants (Fig. 1). Higher GLU and PPO activities occurred for the inoculated plants compared with the noninoculated plants at 8 and 14 dai, respectively (Fig. 1).

Higher TSP concentration occurred at 8 dai for the $-\mathrm{Si}$ inoculated plants of cultivar Bossier compared with the +Si plants (Fig. 2 ). The concentration of LATG derivatives was higher in the $-\mathrm{Si}$ plants than in the + Si plants at 8,14, and 16 dai (Fig. 2). Lower CEL and XYL activities occurred in the -Si plants compared with the + Si plants at 16 dai (Fig. 2). The activities of PME and PG were not affected by Si (Fig. 2). Lower TSP concentrations occurred in the $-\mathrm{Si}$ inoculated plants of cultivar Conquista compared with the + Si plants at 14 and 16 dai (Fig. 2). Higher LATG derivatives concentration occurred in the - $\mathrm{Si}$ plants compared with the +Si plants at 8 dai (Fig. 2). The activities of CEL, XYL, and PG at 14 and 16 dai and the activity of PME at 8, 14, and 16 dai were lower for the $-\mathrm{Si}$ plants than the $+\mathrm{Si}$ plants (Fig. 2). In $-\mathrm{Si}$ inoculated plants of cultivar Bossier, the concentrations of TSP and LATG derivatives were higher at 8 dai and at 8 and 14 dai, respectively, than in the noninoculated plants (Fig. 2). The activities of CEL and XYL were higher in the inoculated plants than in the noninoculated plants at 16 dai (Fig. 2). There was no

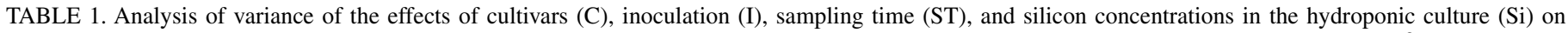

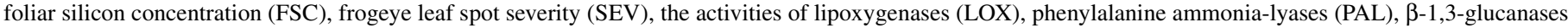

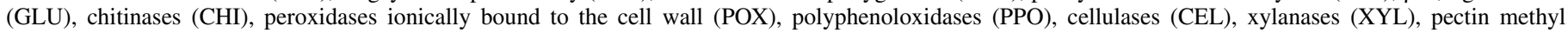
esterases (PME) and polygalacturonases (PG), and the concentrations of total soluble phenolics (TSP) and lignin-thioglycolic acid (LTGA) derivatives

\begin{tabular}{|c|c|c|c|c|c|c|c|c|c|c|c|c|c|c|}
\hline \multirow{2}{*}{$\begin{array}{l}\text { Sources of } \\
\text { variation }\end{array}$} & \multicolumn{14}{|c|}{$F$ values $^{\mathrm{a}}$} \\
\hline & FSC & SEV & LOX & PAL & GLU & $\mathrm{CHI}$ & POX & PPO & CEL & XYL & PME & PG & TSP & LTGA \\
\hline $\mathrm{C}$ & 1.6 & 202.2 & 349.3 & 68.0 & 0.1 & 2.9 & 0.1 & 59.1 & 18.2 & 11.1 & 31.5 & 76.6 & 0.3 & 30.3 \\
\hline I & 0.1 & - & 26.0 & 422.2 & 224.1 & 1177.7 & 877.8 & 112.0 & 358.7 & 127.8 & 30.9 & 66.3 & 7.6 & 488.5 \\
\hline ST & - & - & 72.8 & 16.2 & 4.3 & 49.8 & 18.0 & 32.1 & 64.2 & 25.0 & 0.1 & 16.1 & 26.6 & 91.3 \\
\hline $\mathrm{Si}$ & 384.7 & 24.9 & 3.9 & 40.0 & 2.3 & 3.9 & 76.4 & 7.8 & 76.1 & 40.7 & 41.8 & 46.9 & 4.2 & 60.3 \\
\hline $\mathrm{C} \times \mathrm{I}$ & 0.9 & - & 241.6 & 18.4 & 106.6 & 8.4 & 0.1 & 90.4 & 57.8 & 14.1 & 58.6 & 64.4 & 1.8 & 9.3 \\
\hline $\mathrm{C} \times \mathrm{ST}$ & - & - & 87.6 & 24.7 & 0.4 & 30.2 & 1.6 & 39.5 & 1.7 & 2.4 & 3.5 & 8.6 & 13.1 & 20.1 \\
\hline $\mathrm{C} \times \mathrm{Si}$ & 0.2 & 19.8 & 0.3 & 18.5 & 6.2 & 12.7 & 0.3 & 1.9 & 9.3 & 10.3 & 40.3 & 55.2 & 15.1 & 16.2 \\
\hline $\mathrm{I} \times \mathrm{ST}$ & - & - & 101.9 & 14.4 & 0.7 & 47.8 & 20.9 & 32.8 & 73.7 & 28.1 & 4.0 & 27.4 & 1.3 & 73.1 \\
\hline $\mathrm{I} \times \mathrm{Si}$ & 0.1 & - & 31.8 & 26.8 & 4.3 & 2.2 & 41.0 & 19.5 & 60.5 & 34.2 & 21.0 & 50.4 & 0.5 & 49.5 \\
\hline $\mathrm{ST} \times \mathrm{Si}$ & - & - & 13.1 & 4.1 & 3.3 & 9.5 & 0.6 & 23.2 & 35.3 & 18.6 & 3.3 & 17.5 & 14.5 & 17.0 \\
\hline $\mathrm{C} \times \mathrm{I} \times \mathrm{ST}$ & - & - & 65.2 & 22.8 & 4.8 & 27.6 & 0.7 & 48.2 & 2.4 & 2.3 & 0.3 & 10.3 & 18.5 & 17.2 \\
\hline $\mathrm{C} \times \mathrm{I} \times \mathrm{Si}$ & 0.1 & - & 1.4 & 11.6 & 0.6 & 7.4 & 0.6 & 2.4 & 12.7 & 5.1 & 26.1 & 46.4 & 17.0 & 11.9 \\
\hline $\mathrm{C} \times \mathrm{ST} \times \mathrm{Si}$ & - & - & 11.2 & 6.6 & 8.7 & 13.4 & 0.9 & 5.4 & 3.9 & 0.9 & 1.4 & 10.9 & 3.1 & 3.6 \\
\hline $\mathrm{I} \times \mathrm{ST} \times \mathrm{Si}$ & - & - & 14.4 & 2.7 & 1.0 & 10.6 & 1.2 & 24.7 & 34.3 & 15.8 & 3.3 & 18.2 & 12.1 & 14.1 \\
\hline $\mathrm{C} \times \mathrm{I} \times \mathrm{ST} \times \mathrm{Si}$ & - & - & 13.3 & 2.6 & 6.9 & 13.0 & 0.8 & 4.1 & 4.2 & 1.0 & 1.2 & 21.3 & 1.1 & 1.8 \\
\hline
\end{tabular}

${ }^{a}$ Bold values are significant $(P \leq 0.05)$. 
significant difference between inoculated and noninoculated plants in PME and PG activities at 8, 14, and 16 dai (Fig. 2). The concentration of LATG derivatives was higher in the $-\mathrm{Si}$ inoculated plants of cultivar Conquista compared with their noninoculated counterparts at 8, 14, and 16 dai (Fig. 2). There was no significant difference in TSP concentration between inoculated and noninoculated plants (Fig. 2). CEL activity was higher in inoculated plants compared with noninoculated plants at 8, 14, and 16 dai (Fig. 2), and XYL activity was higher in inoculated plants than noninoculated plants at 8 and 14 dai (Fig. 2). There were no significant differences between inoculated and noninoculated plants in the activities of PME and PG (Fig. 2). In + Si plants of cultivar Bossier, there was no significant difference between inoculated and noninoculated plants in the concentration of TSP (Fig. 2). The concentration of LATG derivatives was higher in the inoculated plants than the noninoculated plants at 8 and 14 dai
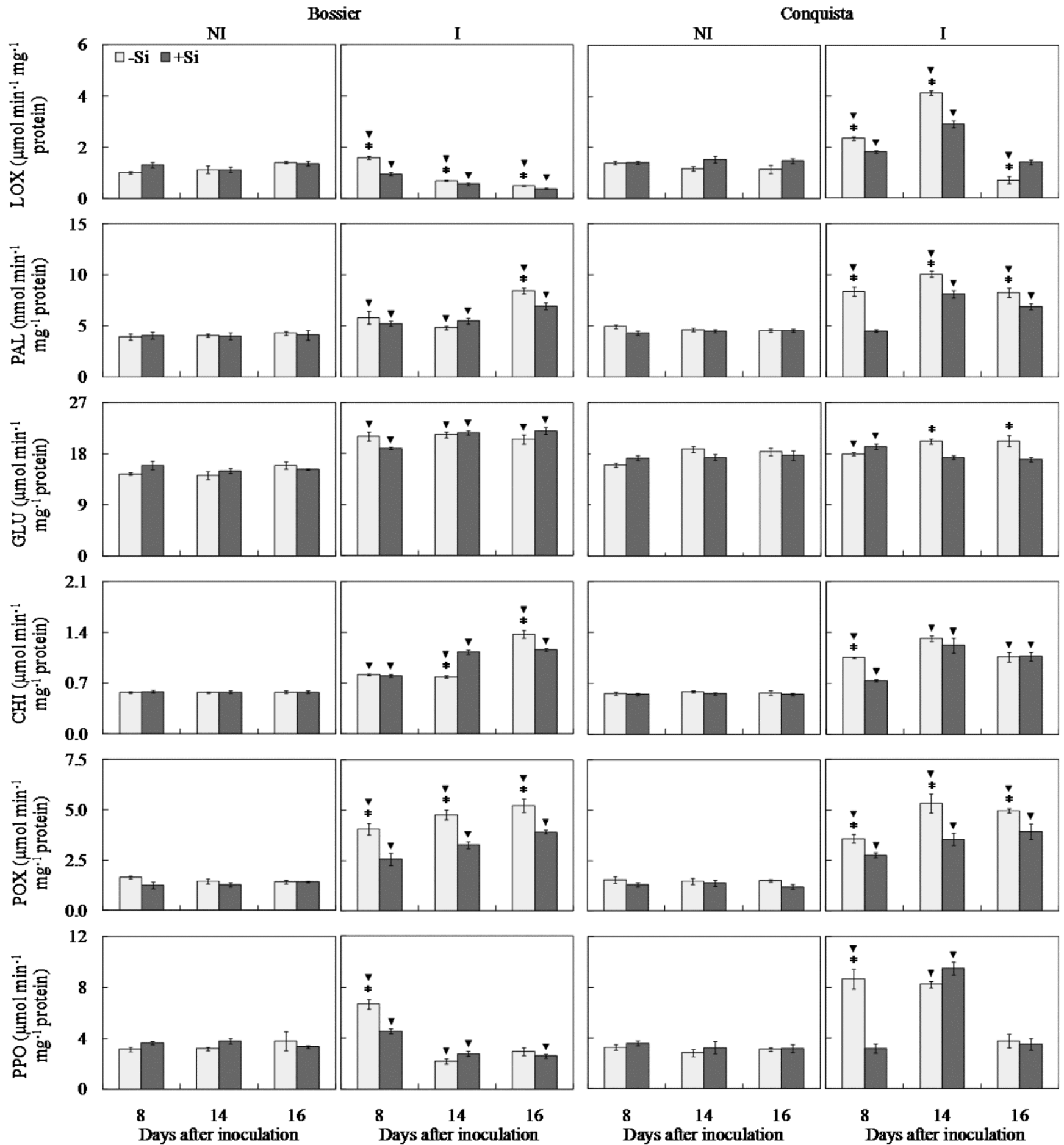

Fig. 1. Activities of lipoxygenases (LOX), phenylalanine ammonia-lyases (PAL), $\beta$-1,3-glucanases (GLU), chitinases (CHI), peroxidases ionically bound to the cell wall (POX), and polyphenoloxidases (PPO) on the leaves of soybean plants from cultivars Bossier and Conquista grown in hydroponic culture containing 0 or $2 \mathrm{mM}$ silicon $(-\mathrm{Si}$ or $+\mathrm{Si}$, respectively) and either inoculated (I) with Cercospora sojina or noninoculated (NI). The means from the $-\mathrm{Si}$ and $+\mathrm{Si}$ treatments within each sampling time and the NI or I treatments followed by an asterisk $\left(^{*}\right)$ are significantly different $(P \leq 0.05)$ according to a $t$ test. The means from the NI and I treatments within each sampling time and the $-\mathrm{Si}$ or $+\mathrm{Si}$ treatments followed by an inverted triangle $(\boldsymbol{\nabla})$ are significantly different $(P \leq 0.05)$ according to a $t$ test. Bars represent the standard errors of the means. Two experiments were conducted and produced consistent results; the data presented represent the most significant results. $n=4$. 
(Fig. 2). There were higher CEL and XYL activities in the inoculated plants compared with the noninoculated plants at 16 dai (Fig. 2). There was no significant difference between inoculated and noninoculated plants in the activities of PME and PG (Fig. 2). In the $+\mathrm{Si}$ inoculated plants of cultivar Conquista, the concentrations of TSP and LATG derivatives were higher at 14 and 16 dai and at 8,14, and 16 dai, respectively, when compared with the noninoculated plants (Fig. 2). Higher activities in CEL and
PME occurred at 8,14, and 16 dai and in XYL and PG at 14 and 16 dai in the inoculated plants compared with the noninoculated plants (Fig. 2).

\section{DISCUSSION}

The results from the present study provide novel biochemical evidence that $\mathrm{Si}$ appears to negatively impact soybean resistance,
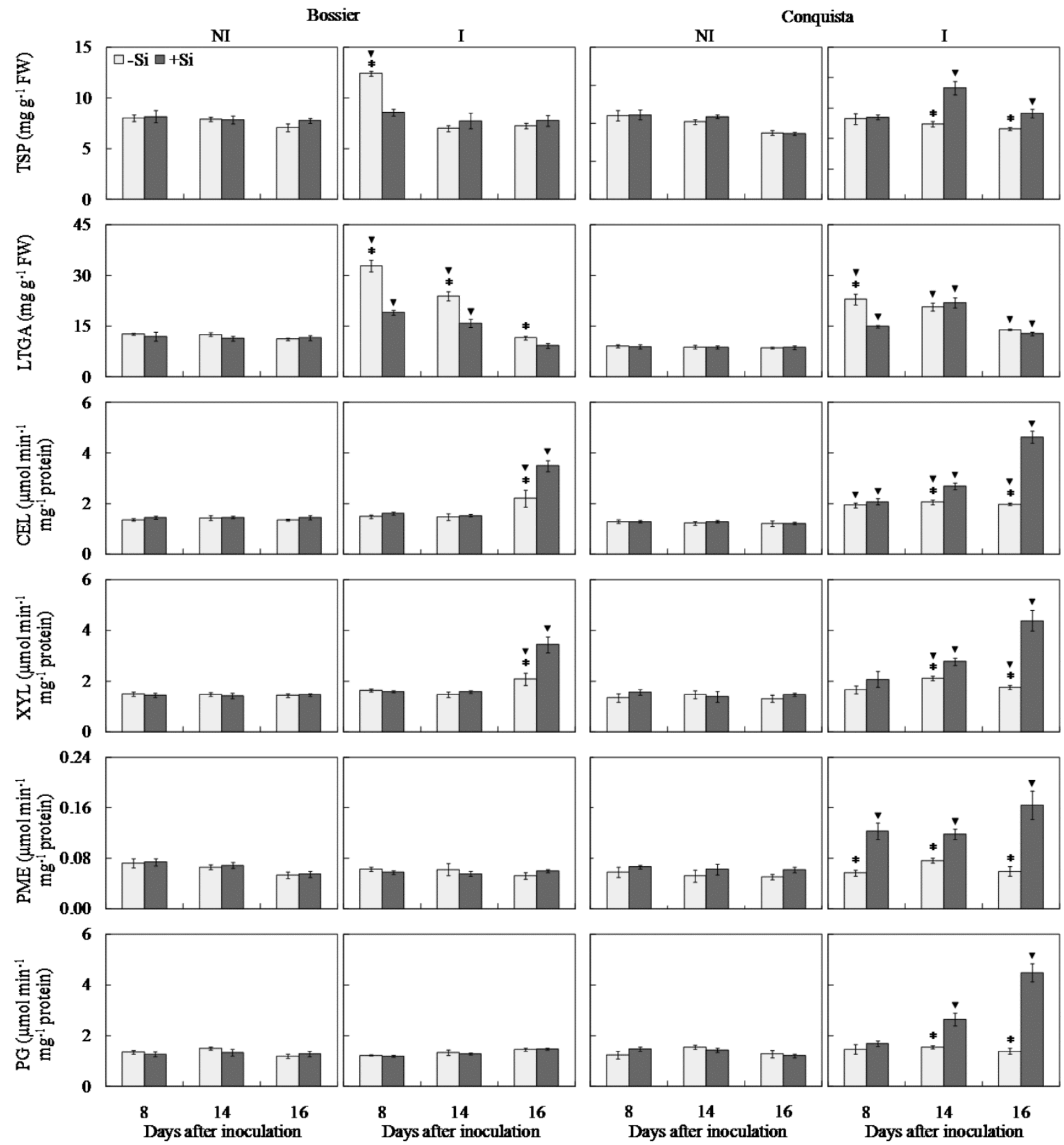

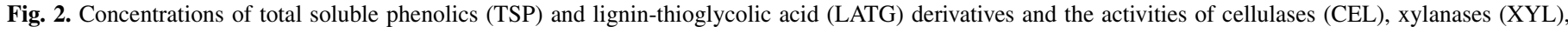

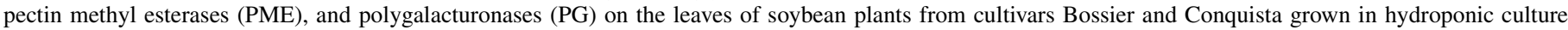

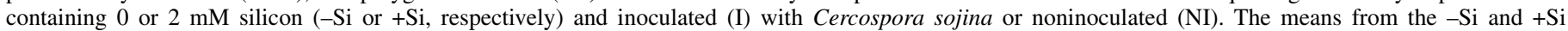

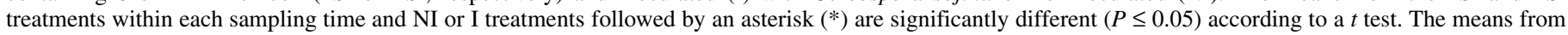

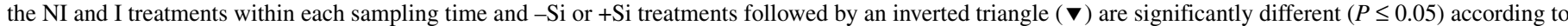

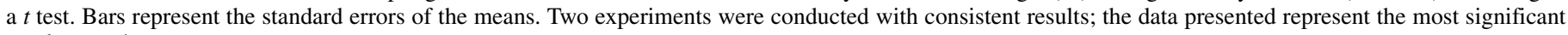
results. $n=4$. 
based on the activities of the defense enzymes and the concentrations of TSP and LATG derivatives, against $C$. sojina infection, regardless of the basal level of resistance of the cultivars used. Chain et al. (10) reported that supplying Si to nonstressed wheat plants minimally altered the expression of some defense genes. Similarly, in Arabidopsis thaliana plants supplied with $\mathrm{Si}$, Fauteux et al. (19) reported no change in the transcription levels for CHI gene, for genes related to pathogenesis-related proteins, or for those involved in the phenylpropanoid pathway. Altogether, the results from the present study point to the conclusion that an effect of $\mathrm{Si}$ on soybean defense metabolism was not expressed in noninoculated plants. Nevertheless, several reports in the literature show that Si enhances biochemical defense mechanisms against many pathogens in several plant species (15, $21,51,54,55,63)$. Surprisingly, the vulnerability of soybean plants to $C$. sojina infection in this study was more pronounced in $+\mathrm{Si}$ plants from the more susceptible cultivar, which showed lower LOX, PAL, GLU, CHI, POX, and PPO activities and a lower concentration of LTGA derivatives.

The secretion of lytic enzymes is an important strategy used by pathogens to gain access to the tissue of their hosts (9). In this study, regardless of exposure to $\mathrm{Si}, C$. sojina infection in soybean plants triggered an increase in the activities of CEL and XYL, suggesting the importance of these two enzymes for its aggressiveness. In addition to CEL and XYL, there was also an increase in the activities of the pectinolytic enzymes, PME and PG, but only in plants from the resistant cultivar supplied with $\mathrm{Si}$ and infected with $C$. sojina. Therefore, based on the higher activities of the cellulolytic and pectinolytic enzymes, these findings corroborate the hypothesis that the process of infection by $C$. sojina was favored in plants from the resistant cultivar and to a lesser extent in the plants from the susceptible cultivar. It is known that higher activity of the lytic enzymes, which degrade the components of the host cell wall, releases sources of carbon and simple sugars that are used as an energy source by the pathogens to achieve tissue colonization (22). However, plants synthesize inhibitor proteins that are able to neutralize the deleterious effects of lytic enzymes such as PG and PME $(45,50)$, which suggests that this phenomenon was limited in the $+\mathrm{Si}$ plants. As reported by Gnanamangai et al. (22), the secretion of pectinolytic enzymes and cellulase by Cercospora theae contributed to increased aggressiveness on plants from Camellia sinensis.

In the present study, increased activities of LOX and PPO on inoculated plants of the resistant cultivar co-occurred with a decrease in their activities on inoculated plants of the susceptible cultivar at 14 dai, which is an evidence of their importance to soybean resistance to frogeye leaf spot. The importance of LOX and PPO activities for plant defense against pathogens has been reported for other host-parasite interactions $(27,35,41,57)$. It is known that an increase in PPO activity raises quinone levels, which, in turn, can negatively impact the growth of many fungi such as Phlyctaena vagabunda, Sclerotinia fructigena, and Venturia inaequalis $(37,38)$. Additionally, the increase in soybean resistance against $C$. sojina infection from higher LOX activity may be due to amplified defense responses based on the involvement of LOX in the production of signaling molecules such as the jasmonic acid and lipid peroxides (26). However, despite the several beneficial effects, elevated activity of LOX can damage cell wall membranes (8) and enhance the development of frogeye leaf spot on soybean leaves as membrane permeability is crucial for successful infection by Cercospora spp. (17). Thus, the reduction in LOX activity at 16 dai in the resistant cultivar plants most likely played a pivotal role in soybean resistance to $C$. sojina infection.

In response to $C$. sojina infection, plants from both cultivars supplied with Si showed increases in POX and PAL activities. Even though the major role played by POX is its contribution to lignin biosynthesis, it also participates in tissue suberization, cross-linking of cell wall structural proteins, auxin catabolism, regulation of senescence, and plant pathogen defense (31). PAL is the major enzyme in the phenylpropanoid pathway that is responsible for the production of several phenolics with antimicrobial proprieties, salicylic acid, and lignin derivatives $(6,58)$. Notably, the increase in POX and PAL activities in the two soybean cultivars infected by $C$. sojina resulted in an increase in the concentration of LATG derivatives. One way in which the LATG derivatives contribute to pathogen defense is by reducing the diffusion of lytic enzymes and nonselective toxins (60). Given that the production and diffusion of nonselective toxins into host tissues greatly contribute to the aggressiveness of Cercospora spp. (18), including $C$. sojina (34), a higher concentration of LATG derivatives may contribute to the reduction of the deleterious effects of $C$. sojina metabolites. Additionally, the more prominent decrease in the concentration of LATG derivatives in $+\mathrm{Si}$ inoculated plants from the susceptible cultivar at 16 dai indicates that maintaining high levels of LATG derivatives is important for soybean resistance against frogeye leaf spot. Although TSP may negatively affect pathogen infection by increasing its membrane permeability (61) and inhibiting pathogenic lytic enzymes (37), the observed increase in the concentration of TSP was not sufficient to counter the deleterious effects of $C$. sojina infection in plants from the two cultivars in the present study. GLU activity was kept higher in plants from the susceptible cultivar throughout the course of fungal infection, but only in the early stages in plants from the resistant cultivar, regardless of Si exposure. Conversely, $\mathrm{CHI}$ activity increased in response to $C$. sojina infection regardless of the cultivar. Therefore, $\mathrm{CHI}$ seems to be more important than GLU in soybean resistance against frogeye leaf spot. Similar to the results from the present study, Roulin and Buchala (56) reported that only CHI was important in Arachis hypogaea resistance to $C$. arachidiola infection.

In conclusion, the results of the present study clearly demonstrate that the basal level of resistance of uninfected soybean plants was not affected by $\mathrm{Si}$, unlike the inoculated plants. However, in the presence of $\mathrm{Si}$ and regardless of their basal level of resistance to frogeye leaf spot, plants' biochemical defenses and their capacity to limit the action of fungal cell wall degrading enzymes were less robust than when $\mathrm{Si}$ was omitted from the nutrient solution.

\section{ACKNOWLEDGMENTS}

Professors F. A. Rodrigues and F. M. DaMatta thank the National Council for Technological and Scientific Development (CNPq) for their fellowships. K. J. T. Nascimento was supported by CNPq (Process 553150/2009-0). This study was supported by grants from Coordenação de Aperfeiçoamento de Pessoal de Nível Superior (CAPES), CNPq and the Fundação de Amparo a Pesquisa do Estado de Minas Gerais (FAPEMIG).

\section{LITERATURE CITED}

1. Ahmed, A. E. R., and Labavith, J. M. 1980. Cell-wall metabolism in ripening fruit. II. Changes in carbohydrate degrading enzymes in ripening Bartlett pears. Plant Physiol. 65:1014-1016.

2. Almeida, A. M. R., Ferreira, J. T., Yorinori, J. F. V., Henning, A. A., Godoy, C. V., Costamilan, L. M., and Meyer, M. C. 2005. Doenças da Soja (Glycine max). Page 574 in: Doenças das Plantas Cultivadas. H. Kimati, L. Amorim, J. A. M. Rezende, A. Bergamin, and L. E. A. Camargo, eds. Editora Agronômica Ceres Ltda., Piracicaba, SP.

3. Arsenault-Labrecque, G., Menzies, J. G., and Bélanger, R. R. 2012. Effect of silicon absorption on soybean resistance to Phakopsora pachyrhizi in different cultivars. Plant Dis. 96:37-42.

4. Axelrod, B., Cheesbrough, T. M., and Laasko, S. 1981. Lipoxygenases from soybeans. Methods Enzymol. 71:441-451.

5. Barber, M. S., and Ride, J. P. 1988. A quantitative assay for induced lignification in wounded wheat leaves and its use to survey potential elicitors of the response. Physiol. Mol. Plant Pathol. 32:185-197.

6. Borges, A., Melotto, M., Tsai, S. M., and Caldas, D. G. G. 2012. Changes 
in spatial and temporal gene expression during incompatible interaction between common bean and anthracnose pathogen. J. Plant Physiol. 169:1216-1220.

7. Bradford, M. N. 1976. A rapid and sensitive method for the quantitation of microgram quantities of protein utilizing the principle of protein-dye binding. Anal. Biochem. 72:248-254.

8. Brash, A. R. 1999. Lipoxygenases: Occurrence, functions, catalysis, and acquisition of substrate. J. Biol. Chem. 20:23679-23682

9. Cantu, D., Vicente, A. R., Labavitch, J. M., Bennett, A. B., and Powell, A. L. T. 2008. Strangers in the matrix: Plant cell walls and pathogen susceptibility. Trends Plant Sci. 13:610-616.

10. Chain, F., Côté-Beaulieu, C., Belzile, F., Menzies, J. G., and Bélanger, R. R. 2009. A comprehensive transcriptomic analysis of the effect of silicon on wheat plants under control and pathogen stress conditions. Mol. PlantMicrobe Interact. 22:1323-1330.

11. Chance, B., and Maehley, A. C. 1955. Assay of catalases and peroxidases. Method Enzymol. 2:764-775.

12. Clark, R. B. 1975. Characterization of phosphatase of intact maize roots. J. Agric. Food Chem. 23:458-460.

13. Cruz, M. F. A., Rodrigues, F. A., Rodriguez, L. P., Curvelo, C. R. S., Nascimento, K. J. T., Moreira, M. A., and Barros, E. G. 2013. Inducers of resistance and silicon on the activity of defense enzymes in the soybeanPhakopsora pachyrhizi interaction. Bragantia 72:162-172.

14. Cruz, M. F. A., Silva, F. S., Rodrigues, F. A., Araujo, J. M., and Barros, E. G. 2012. Silício no processo infeccioso de Phakopsora pachyrhizi em folíolos de plantas de soja. Pesqui. Agropecu. Bras. 47:142-145.

15. Dallagnol, L. J., Rodrigues, F. A., DaMatta, F. M., Mielli, M. V. B., and Pereira, S. C. 2011. Deficiency in silicon uptake affects cytological, physiological, and biochemical events in the rice-Bipolaris oryzae interaction. Phytopathology 101:92-104.

16. Datnoff, L. E., Rodrigues, F. A., and Seebold, K. 2007. Silicon and plant disease. Pages 233-246 in: Mineral Nutrition and Plant Disease. L. E. Datnoff, W. E. Elmer, and D. M. Huber, eds. The American Phytopathological Society, St. Paul, MN.

17. Daub, M. E. 1982. Peroxidation of tobacco membrane lipids by the photosensitizing toxin, cercosporin. Plant Physiol. 69:1361-1364.

18. Daub, M. E., Herrero, S., and Chung, K.-R. 2013. Reactive oxygen species in plant pathogenesis: The role of perylenequinone photosensitizers. Antioxid. Redox Signal. 19:970-989.

19. Fauteux, F., Chain, F., Belzile, F., Menzies, J. G., and Bélanger, R. R. 2006. The protective role of silicon in the Arabidopsis-powdery mildew pathosystem. Proc. Natl. Acad. Sci. USA 103:17554-17559.

20. Fehr, W. R., Caviness, C. E., Burmood, D. T., and Pennington, J. S. 1971. Stage of development descriptions for soybeans, Glycine max (L.) Merrill. Crop Sci. 11:929-931.

21. Fortunato, A. A., Rodrigues, F. A., and Nascimento, K. J. T. 2012. Physiological and biochemical aspects of the resistance of banana plants to Fusarium wilt potentiated by silicon. Phytopathology 102:957-966.

22. Gnanamangai, B. M., Ponmurugan, P., Yazhini, R., and Pragadeesh, S. K. 2011. PR enzymes activities of Cercospora theae causing bird's eye spot disease in tea plants (Camellia sinensis (L.) O.kuntze). J. Plant Pathol. 10:13-21.

23. Gravina, G. A., Sediyama, C. S., Martins, S. F., Moreira, M. A., and Cruz, C. D. 2004. Multivariate analysis of combining ability for soybean resistance to Cercospora sojina Hara. Genet. Mol. Biol. 27:395-399.

24. Guo, Y., Liu, L., and Bi, Y. 2007. Use of silicon oxide and sodium silicate for controlling Trichothecium roseum postharvest rot in Chine cantaloupe (Cucumis melo L.). Int. J. Food Sci. Technol. 42:1012-1018.

25. Hagerman, A. E., and Austin, P. 1986. Continuous spectrophotometric assay for plant pectin methyl esterase. J. Agric. Food Chem. 34:440-444.

26. Hammond-Kosack, K. E., and Jones, J. D. G. 1996. Resistance genedependent plant defense responses. Plant Cell 8:1773-1791.

27. Hao, Z., Wang, L., Liang, J., and Tao, R. 2012. Expression of defense genes and activities of antioxidant enzymes in rice resistance to rice stripe virus and small brown planthopper. Plant Physiol. Biochem. 7:744-751.

28. Harman, G. R., Hayes, C. K., Lorito, M., Broadway, R. M., Pietro, A. D., Peterbauer, C., and Tronsmo, A. 1993. Chitinolytic enzymes of Trichoderma harzianum: Purification of chitobiosidase and endochitinase. Phytopathology 83:313-318.

29. Hartman, L., Sinclair, J. B., and Rupe, J. C. 1999. Compendium of Soybean Diseases. 4th ed. The American Phytopathological Society, St Paul, MN.

30. Hayasaka, T., Fujii, H., and Ishiguro, K. 2008. The role of silicon in preventing appressorial penetration by the rice blast fungus. Phytopathology 98:1038-1044.

31. Hiraga, S., Sasaki, K., Ito, H., Ohashi, Y., and Matsui, H. 2001. A large family of class III plant peroxidases. Plant Cell Physiol. 42:462-468.

32. Kar, M., and Mishra, D. 1976. Catalase, peroxidase, and polyphenoloxidase activities during rice leaf senescence. Plant Physiol. 57:315-319.

33. Kim, H., Newell, A. D., Cota-Sieckmeyer, R. G., Rupe, J. C., Fakhoury,
A. M., and Bluhm, B. H. 2013. Mating-type distribution and genetic diversity of Cercospora sojina populations on soybean from Arkansas: Evidence for potential sexual reproduction. Phytopathology 103:10451051.

34. Kim, J. S., Lee, Y. S., Kim, S. K., Kim, K. D., and Kim, J. W. 2011. Differential responses of soybean cultivars to Cercospora sojina isolates, the causal agent of frogeye leaf spot in Korea. Plant Pathol. J. 27:183-186.

35. Kolomiets, M. V., Chen, H., Gladon, R. J., Braun, E. J., and Hannapel, D. J. 2000. A leaf lipoxygenase of potato induced specifically by pathogen infection. Plant Physiol. 124:1121-1130.

36. Korndörfer, G. H., Pereira, H. S., and Nolla, A. 2004. Análise de silício: Solo, planta e fertilizante. Uberlândia, MG, Brasil. Boletim Técnico. Universidade Federal de Uberlândi.

37. Lattanzio, V., Lattanzio, V. M. T., and Cardinali, A. 2006. Role of phenolics in the resistance mechanisms of plants against fungal pathogens and insects. Phytochemistry 37:23-67.

38. Lattanzio, V., Venere, D. D., Linsalata, V., Bertolini, P., Ippolito, A., and Salerno, M. 2001. Low temperature metabolism of apple phenolics and quiescence of Phlyctaena vagabunda. J. Agric. Food Chem. 49:58175821.

39. Lemes, E. M., Mackowiak, C. L., Blount, A., Marois, J. J., Wright, D. L., Coelho, L., and Datnoff, L. E. 2011. Effects of silicon applications on soybean rust development under greenhouse and field conditions. Plant Dis. 95:317-324.

40. Lever, M. 1972. A new reaction for colorimetric determination of carbohydrates. Anal. Biochem. 47:273-279.

41. Li, L., and Steffens, J. C. 2002. Overexpression of polyphenol oxidase in transgenic tomato plants results in enhanced bacterial disease resistance. Planta 215:239-247.

42. Liang, Y. C., Hua, H., Zhu, Y. G., Zhang, J., Cheng, C., and Römheld, V. 2006. Importance of plant species and external silicon concentration to active silicon uptake and transport. New Phytol. 172:63-72.

43. Lucena, J. A. M., Castal, M. F. C., Casela, C. R., Vernetti, F. J. 1982. Herança da resistência à raça 4 de Cercospora sojina Hara em soja. Pesqui. Agropecu. Bras. 17:1751-1755.

44. Ma, J. F., Tamai, K., Ichii, M., and Wu, G. F. 2002. A rice mutant defective in Si uptake. Plant Physiol. 130:2111-2117.

45. Mahalingam, R., Wang, G., and Knap, H. T. 1999. Polygalacturonase and polygalacturonase inhibitor protein: Gene isolation and transcription in Glycine max-Heterodera glycines interactions. Mol. Plant-Microbe Interact. 12:490-498.

46. Miller, G. L. 1959. Use of dinitro salicylic acid reagent for determination of reducing sugar. Anal. Chem. 31:426-428.

47. Missaoui, A. M., Ha, B. K., Phillips, D. V., and Boerma, H. R. 2007. Single nucleotide polymorphism detection of the Rcs 3 gene for resistance to frogeye leaf spot in soybean. Crop Sci. 47:1681-1690.

48. Pathak, N. S., and Sanwal, G. G. 1998. Multiple forms of polygalacturonase from banana fruits. Phytochemistry 48:249-255.

49. Ranieri, A., Castagna, A., Baldan, B., and Soldatini, G. F. 2001. Iron deficiency differently affects peroxidases isoforms in sunflower. J. Exp. Bot. 52:25-35

50. Reignault, O., Valette-Collet, O., and Boccara, M. 2008. The importance of fungal pectinolytic enzymes in plant invasion, host adaptability and symptom type. Eur. J. Plant Pathol. 120:1-11.

51. Resende, R. S., Rodrigues, F. A., Cavatte, P. C., Martins, S. C. V., Moreira, W. R., Chaves, A. R. M., and DaMatta, F. M. 2012. Leaf gas exchange and oxidative stress in sorghum plants supplied with silicon and infected by Colletotrichum sublineolum. Phytopathology 102:892-898.

52. Rodrigues, F. A., Benhamou, N., Datnoff, L. E., Jones, J. B., and Bélanger, R. R. 2003. Ultrastructural and cytochemical aspects of siliconmediated rice blast resistance. Phytopathology 93:535-545.

53. Rodrigues, F. A., Duarte, H. S. S., Domiciano, G. P., Souza, C. A., Korndörfer, G. H., and Zambolim, L. 2009. Foliar application of potassium silicate reduces the intensity of soybean rust. Australasian Plant Pathol. 38:15-21.

54. Rodrigues, F. A., Jurick, W. M., II, Datnoff, L. E., Jones, J. B., and Rollins, J. A. 2005. Silicon influences cytological and molecular events in compatible and incompatible rice-Magnaporthe grisea interactions. Physiol. Mol. Plant Pathol. 66:144-159.

55. Rodrigues, F. A., McNally, D. J., Datnoff, L. E., Jones, J. B., Labbe, C., Benhamou, N., Menzies, J. G., and Bélanger, R. R. 2004. Silicon enhances the accumulation of diterpenoid phytoalexins in rice: A potential mechanism for blast resistance. Phytopathology 94:177-183.

56. Roulin, S., and Buchala, A. J. 1995. The induction of $\beta$-1,3-glucanases and other enzymes in groundnut leaves infected with Cercospora arachidicola. Physiol. Mol. Plant Pathol. 46:471-489.

57. Sahoo, M. R., Kole, P. C., Dasgupta, M., and Mukherjee, A. 2009. Changes in phenolics, polyphenol oxidase and its isoenzyme patterns in relation to resistance in taro against Phytophthora colocasiae. J. Phytopathol. 157:145-153. 
58. Schuster, B., and Rétey, J. 1995. The mechanism of action of phenylalanine ammonia-lyase: The role of prosthetic dehydrolanine. Proc. Natl. Acad. Sci. USA 92:8433-8437.

59. Singh, A., and Singh, M. 1993. Cell-wall degrading enzymes in Orobanche aegyptiaca and its host Brassica campestris. Plant Physiol. 89:177-181.

60. Siranidou, E., Kang, Z., and Buchenauer, H. 2002. Studies on symptom development, phenolic compounds and morphological defense responses in wheat cultivars differing in resistance to Fusarium head blight. J. Phytopathol. 150:200-208.

61. Tomás-Barberán, F., Iniesta-Sanmartín, E., Tomás-Lorente, F., and Rumbero, A. 1990. Antimicrobial phenolic compounds from three Spanish helichrysum species. Phytochemistry 29:1093-1095.
62. Vale, F. X. R., Fernandes Filho, E. I., and Liberato, J. R. 2003. QUANT: A software plant disease severity assessment. R. Close, M. Braithwaite, and I. Havery, eds. Proceedings of the 8th International Congress of Plant Pathology, New Zealand.

63. Xavier Filha, M. S., Rodrigues, F. A., Domiciano, G. P., Oliveira, H. V., Silveira, P. R., and Moreira, W. R. 2011. Wheat resistance to leaf blast mediated by silicon. Austral. Plant Pathol. 40:28-38.

64. Zieslin, N., and Ben-Zaken, R. 1993. Peroxidase activity and presence of phenolic substances in peduncles of rose flowers. Plant Physiol. Biochem. 31:333-339.

65. Zucker, M. 1965. Induction of phenylalanine deaminase by light and its relation to chlorogenic acid synthesis in potato tuber tissue. Plant Physiol. 40:779-784. 